\title{
PRODUCTIVITY OF CATALAN FIRMS INTERNATIONAL EXPOSURE AND (PRODUCT) INNOVATION
}

\author{
Bruno Cassiman \\ Elena Golovko
}


The Public-Private Center is a Research Center based at IESE Business School. Its mission is to develop research that analyses the relationships between the private and public sectors primarily in the following areas: regulation and competition, innovation, regional economy and industrial politics and health economics.

Research results are disseminated through publications, conferences and colloquia. These activities are aimed to foster cooperation between the private sector and public administrations, as well as the exchange of ideas and initiatives.

The sponsors of the SP-SP Center are the following:

- Accenture

- Ajuntament de Barcelona

- Caixa Manresa

- Cambra Oficial de Comerç, Indústria i Navegació de Barcelona

- Consell de l'Audiovisual de Catalunya

- Departamento de Economía y Finanzas de la Generalitat de Catalunya

- Departamento de Innovación, Universidades y Empresa de la Generalitat de Catalunya

- Diputació de Barcelona

- Endesa

- Fundació AGBAR

- Garrigues

- Mediapro

- Microsoft

- Sanofi Aventis

- VidaCaixa

The contents of this publication reflect the conclusions and findings of the individual authors, and not the opinions of the Center's sponsors. 


\title{
PRODUCTIVITY OF CATALAN FIRMS INTERNATIONAL EXPOSURE AND (PRODUCT) INNOVATION
}

\author{
Bruno Cassiman ${ }^{1}$ \\ Elena Golovko²
}

\begin{abstract}
Exporting firms are typically the more productive firms in an economy. Based on this observation, policy makers typically enacted policies to stimulate exportation by domestic firms. In this chapter, we argue that firms make productivity enhancing investments and as a result the more productive firms start an export activity, which might make these firms even more productive. We find evidence of two types of productivity enhancing investments made by Catalan firms: both the fact that a firm imports some of its inputs, and, that the firm has innovated in the previous year seem to positively affect productivity and, hence, the decision to start exporting. We also find that there is an important difference between the effects of product innovations versus process innovations: product innovations seem to matter more for the export decision of Catalan firms while process innovations have little or no effect on this decision. Overall, we find that importing, innovating and exporting are strongly complementary activities. At the same time these activities are developed sequentially by the firms. Therefore, it seems that stimulating firms to be active in the international sourcing market and generating (product) innovations might be more productive policy measures than stimulating firms to enter the export market directly.
\end{abstract}

Keywords: Firms, Productivity, Catalonia, Innovation.

\footnotetext{
${ }^{1}$ Professor, Strategic Management, IESE, KULeuven and CEPR

2 Tilburg University
} 


\section{PRODUCTIVITY OF CATALAN FIRMS INTERNATIONAL EXPOSURE AND (PRODUCT) INNOVATION}

\section{Introduction}

Firms are born, make decisions, thrive or die. This dynamic process of firm lifecycles generates a tremendous amount of heterogeneity among firms not only across industries, but more interestingly, also within industries (Bartelsman and Doms, 2000).

Most of the theoretical models on industry dynamics assume that firms are born with an inherent ability, their productivity. Efficient firms survive and grow in the market, while inefficient firms, with productivity below a certain threshold, decline and fail (Jovanovic 1982; Hopenhayn 1992). These models, however, assume that the productivity distribution across firms is exogenous to firms, thus relating firm survival to "luck of the draw". Firms with low productivity exit, while "lucky" firms with high productivity survive and continue growing. Little room is left for firm decisions, except for the decision on exiting, which is endogenized.

While theoretically such heterogeneity and dynamics is difficult to handle, empirically it provides a wealth of interesting observations. Nevertheless, we know very little about the connection between individual firm decisions and their dynamic consequences. One of the basic empirical facts related to productivity is a strong positive association between productivity and exporting activity at the firm level. Most of the studies explain this pattern by self-selection of more efficient firms into the export market (Clerides, Lach et al. 1998; Bernard and Jensen 1999; Delgado, Fariñas et al. 2002; Fafchamps, El Hamine et al. 2007), confirming the sunk cost hypothesis that only those firms who are efficient enough to bear entry costs and intense competition of the export market will start exporting. This suggests that a closer examination of prior firm decisions might be needed to understand this important selection.

In this paper, we take a first step towards explaining the observed productivity-export link. Following Lieeva and Treffler (2007) we argue that a potential underlying mechanism for the selection of more productive firms into exporting is related to the firm's investment decisions. Furthermore, exporting enhances the return to such investment decisions and as such is complementary to the productivity enhancing investment decisions. We will examine two simple mechanisms that have been suggested to enhance productivity: innovation and imports. 
Innovation. The findings of the empirical studies show that one of the important sources of the productivity heterogeneity at the firm level is related to R\&D and innovation activities (see Griliches, 1998). Moreover, recent productivity literature has found evidence suggesting that firm specific demand variation, rather than technical efficiency, is the dominant factor in determining firm survival and positively influencing measured productivity (Foster et al. 2006). This suggests that product innovation related to positive demand shocks rather than innovation in process related to production efficiency could be responsible for the increase in measured productivity and, consequently, entry into exporting.

Consistent with this argument, empirical findings show that product innovation plays an important role in explaining the export decision of a firm. In a related paper, Cassiman and Martinez-Ros (2007) find that firms with product innovation are significantly more likely to become exporters than non-innovators. Accounting for innovation, then, may be critical in explaining the strong positive correlation between exporting and productivity in the existing research findings. We thus argue that the observed productivity-export link may be partly explained by the firm's innovation status.

Following Vernon (1966) in his very influential paper on the internationalization of US business, we argue that the first step in such an internationalization process of the firm is the decision to start exporting. Young firms possess a new product in the early phase of the product lifecycle based on proprietary knowledge. As the domestic market is limited in the early innovation stage the firm moves to enter into the export market to exploit their market power (Hirsch and Bijaoui, 1985). At this stage of the product lifecycle the product is new and needs a close interaction between product development and manufacturing for which production remains in the (main) domestic market (Antras, 2005). Furthermore, as Klepper (1996) has shown, product innovation dominates the early stage of the product lifecycle, while process innovation enters in later stages when production volumes have picked up and make this latter type of innovation relatively more attractive.

Following the product lifecycle logic we, therefore, believe that successful product innovation will induce the firm to enter the export market. A potential underlying mechanism for the move of more productive firms into the export market is, therefore, that successful (product) innovation improves the firm's productivity, and, hence, the more productive firm moves into the export market. Nevertheless, we acknowledge that anything affecting productivity - not only product innovation - could induce the firm to enter the export market.

Imports. Imports and in particular higher quality imports and imports with high technology content might enhance the productivity of firms in the economy. This effect can run directly through the importing firms or indirectly through spillover effects to the firms in the same sector and the rest of the economy. Recent work by Amiti and Konings (2007) has confirmed the quantitative importance of this effect. They find that a reduction in trade tariffs affects the firms importing these goods as intermediate inputs more than the import competing firms. The effect of a trade tariff reduction, therefore, improves productivity of importing firms more than the productivity of domestic import competing firms. Imports, hence, serve as an important productivity enhancing mechanism. 
Connecting Imports and Innovation. Furthermore, we argue that innovation and imports are probably not independent. As firms import higher quality inputs, new materials and components, they are able to transform them in higher quality outputs while developing new and better products. We should, therefore expect imports - or firm internationalization on the input side - to be highly related to innovation and, as a consequence, productivity improvements.

We investigate the export-productivity link of the firms that engage in productivity enhancing activities such as importing and innovating using a panel of Spanish manufacturing firms. First we look at a series of descriptive statistics relating imports, innovation and exports. Next, we perform a number of regressions trying to explain the decisions to import, innovate and export. And, finally, we compare the cumulative productivity distributions of firms importing, innovating and exporting, or a combination thereof.

Our findings suggest that the successful firms in the Catalan economy import, innovate and export. Our findings could have important policy implications. If these investments are a source of productivity growth, then policies aimed at promoting imports and innovation, and product innovation in particular, might be more effective than direct export promotions, at least for firms "at risk" for importing and innovating. The key policy issue then becomes which type of investment to leverage. While exports do seem strongly correlated with firm productivity, we argue that imports and innovation precede the export decision of these successful firms.

The paper proceeds as follows. In Section 2 we discuss the related literature. Sections 3 and 4 describe the data and methodology used in this study. Section 5 presents the results of the empirical analysis. A discussion section concludes.

\section{The Export-Productivity Link and Productivity Enhancing Investments}

In the empirical international trade literature, the positive association between exports and firm productivity has been well-documented. At least two explanations for the observed exportproductivity link have been suggested. On the one hand, the positive association between exporting and productivity is explained through a selection mechanism. On the other hand, there is the possibility of learning-by-exporting - exporters may learn from their foreign contacts, adopting new production technologies and increasing productivity.

With both mechanisms being plausible, empirical evidence is rather unanimous in supporting the selection hypothesis behind the export-productivity link where sunk start-up costs associated with becoming an exporter lead to the self-selection of more productive firms into exporting. The hysteresis in exporting serves as evidence for the sunk entry costs in the export market (Roberts and Tybout 1997; Clerides, Lach and Tybout 1998; Bernard and Jensen 1999; Aw, Chen and Roberts 2001; Delgado, Farinas et al. 2002; Fafchamps, El Hamine et al. 2007). Furthermore, the general finding in developed countries is that exporting firms have higher productivity than nonexporters before taking up exports and no significant productivity advantages are observed among continuous exporters or non-exporting firms respectively over time.

Such heterogeneity in productivity raises an important question about the sources of high productivity of these exporting firms. How do firms obtain higher productivity levels that allow them to enter the export market? International trade literature, following the work on industry dynamics (Jovanovic 1982; Hopenhayn 1992), has attempted to incorporate firm heterogeneity 
in the international trade modeling. Recent theoretical work by Melitz (2003) and Bernard et al. (2003) formulates theories that reflect the empirical regularities observed in the exporting behavior and productivity. In these theories, the initial productivity level of a firm is determined by a random draw from a known distribution function. The model by Melitz (2003) assumes sunk entry costs in the export market, while Bernard et al. (2003) assume Bertrand competition among producers, which only allows the most productive firms to incur trading costs associated with exports. Thus, these theories demonstrate the selection mechanism of more productive firms into the export market. The models, however, do not explain why these firms are more productive and self-select into exporting, that is, the theories are not causal theories between firm decisions and their decision to export.

Innovation. One important source of productivity differences seems to be related to R\&D and innovation activities (See Griliches, 1998). A number of empirical studies have documented the positive and significant effect of R\&D and innovation on firm productivity and productivity growth. Crepon et al. (1998), estimating a structural model that links productivity, innovation output and innovation inputs, find that firm productivity correlates positively with higher innovation output. In line with their result, Jefferson et al. (2004), for Chinese firms, show that new product sales are positively associated with productivity. Huergo and Jaumandreu (2004), using the panel of Spanish firms, find that process innovation is an important determinant of productivity growth at the firm level. Investigating the relationship between innovation and productivity in four European countries, Griffith et al. (2006) find - consistent with the previous studies - that both product and process innovations have a positive significant effect on firm-level productivity in three out of the four countries. Finally, Doraszelski and Jaumandreu (2007) revisit the knowledge capital framework within an extension of Erickson and Pakes (1995) and find important effects of R\&D investments on productivity.

At the same time, R\&D and innovation activities seem to play an important role in explaining a firm's decision to export and its export volumes. In particular, recent studies find that innovation is an important driver of the export decision. Basile (2001), for a sample of Italian manufacturing firms, shows that firms introducing product and/or process innovations either through R\&D or through investments in new capital are more likely to export. Bernard and Jensen (2004) find that firms switching primary SIC code - which could indicate new product introductions - significantly increase the probability of entering the export markets. In a related paper, Cassiman and Martinez-Ros (2007) find that product innovation is an important determinant of the firm's exporting activities. Thus, taken together, prior empirical findings suggest that innovation activity may be responsible for both the productivity enhancement and export orientation of a firm and may explain the correlation between exports and productivity.

A number of studies provide empirical support for the direction of our argument. Aw and Batra (1998), on a sample of Taiwanese firms, find that, for the group of large, high-technology firms, exporters do not differ from non-exporters in their efficiency levels. However, in the group of small firms with no formal investments in technology, exporters are significantly closer to the production frontier than non-exporting firms. Delgado et al. (2002), using a sample of Spanish firms, show that the export-productivity link varies depending on firm size. They observe no significant difference in productivity levels between exporters and non-exporters for larger firms. But for small firms, exporters show significantly higher productivity levels than nonexporters. In a recent paper, Aw et al. (2007) find that, for firms that do not invest in R\&D, productivity of exporters is significantly higher than that of non-exporting firms. Moreover, firms that export and invest in R\&D are found to have higher productivity than those that only export. This evidence is used to argue that, not only do more efficient firms select into the

4 - IESE Business School-University of Navarra 
export market, but exports and R\&D are important and complementary sources of productivity growth, with R\&D activities facilitating the assimilations of the benefits from export markets. These findings, coupled with the well-documented positive link between innovation and firm size (although possibly at a decreasing rate), point to the importance of innovation as a possible explanatory variable driving the export-productivity link.

Therefore, connecting innovation, productivity and exports, we argue that accounting for innovation might take us some way in explaining the positive association between exports and productivity. Furthermore, in a related paper, Cassiman and Martinez-Ros (2007) find a strong positive effect of product - but not process - innovation on the decision of a firm to export. Consistent with that, Foster et al. (2006) find that firm-specific demand shocks rather than production-efficiency shocks explain differences in measured productivity, suggesting that product innovation rather than process innovation might improve measured productivity more (and, consequently, drives the decision to export). Hence, we would expect that product rather than process innovation matters for explaining the positive correlation between productivity and exports.

Imports. The importance of imports and the effect of import tariffs on firm level productivity has been the subject of recent debate in the international trade literature. While lower output tariffs were claimed to have an important impact on enhancing productivity through increased import competition, the work by Amiti and Konings (2007) shows that imports and import tariff reductions directly affect productivity of the importing firms and of other firms in the industry through externalities inflicted. For Indonesian firms this effect is twice as large as output tariff decreases. Theoretical work by Ethier (1982), Markusen (1989) and Grossman and Helpman (1991) had argued such effects through access to more varieties of intermediate inputs, access to higher quality inputs and through learning effects.

One important channel of productivity improvements might be through access to better technology and higher quality machinery. Veugelers and Cassiman (2004) for example found that firms active on the international technology market are also more likely to be active in the domestic technology market, implying that direct and indirect productivity enhancements in the local economy would be generated through these firms access to the international technology markets. Belderbos et al. (2008) does find these productivity enhancements for the case of Flemish firms.

\section{Data}

The data used in this study come from a survey (ESEE) of Spanish manufacturing firms started in 1990 with data collected annually up to 2006. The project was conducted by the Fundación Empresa Pública with financial support from the Spanish Ministry of Science and Technology. The information collected each year is consistent with the information in the previous years. The sample includes the population of Spanish manufacturing firms with 200 or more employees. It also contains a stratified sample of small firms comprising $4 \%$ of the population of small firms with more than 10 and fewer than 200 employees. Small firms that exited the original sample during the sampling period were replaced by firms with similar characteristics 
drawn from the population. ${ }^{1}$ Previous research has used the same data set as it is representative for the Spanish manufacturing industry over this period (Delgado et al (2002); Campa (2004); Huergo and Jaumandreu (2004); Cassiman and Martines-Ros (2007); Doraszelski and Jaumandreu (2007), among others).

The original sample includes 2,188 firms in 1990 and 4,357 firms in 2006 from 20 distinctive industries. Due to entry, exit, and missing values, the resulting sample is an unbalanced panel with 29,431 firm-year observations. The survey also contains information on the province where firms are located. Catalan firms constitute on average $13.4 \%$ of firms in the original sample, ranging from $24.1 \%$ in 1990 to $8.8 \%$ in $2006 .^{2}$ In the final sample, the percentage of Catalan firms ranges from $24.3 \%$ in 1990 to $19 \%$ in 2006 with the average of $23 \%$, which is 6,806 firm-year observations. We divide the overall time period 1990-2006 into two sub periods 1990-1999 and 2000-2006, to compare the performance of Catalan firms for these two time spans. The focus is on small and medium enterprises, i.e., those firms that have less than 200 employees in 1990.

Table 1 presents information on the distribution of exporting, importing and innovating firms by year. The proportion of exporting firms has increased significantly from 51\% in 1991 to $62 \%$ in 2006 for all firms, and from 59\% to 76\% for Catalan firms. The percentage of firms with product and process innovations does show some variation during the sample period, but the change does not seem to be significant. The proportion of Catalan firms with product innovation has slightly decreased from 30\% in 1991 to $27 \%$ in 2006, while the proportion of firms with process innovation did not change significantly - from 38\% in 1991 to 37\% in 2006. We observe a significant increase in the proportion of firms with import activities - from 63\% in 1991 to more than 74\% in 2006. The results for value added per employee show that the level of value added (non deflated) has increased significantly over the period 1990-2006 from 36,000 Euros up to 73,000 Euros on average for the sub sample of small Catalan firms.

The graphs in Figure 1 summarize the development of export and import volumes for the Catalan economy over 1994-2006 ${ }^{3}$. Figure 1 shows in particular how export and import start diverging after 2000 for some important sectors in the Catalan economy such as Textiles, Machinery and Equipment, Office Machinery and Computing, and Equipment, while for others such as Food, Tobacco and Beverages or Chemicals, the difference remains rather constant over time. This variation might help identify the separate effect of imports on productivity and exports as a consequence. This effect should be stronger in industries where the divergence between imports and exports has been stronger.

\footnotetext{
${ }^{1}$ Proportion of the firms in the year $t$ that continue in the survey in the year $t+1$ is approximately $90 \%$ for the 1990 2001 sample period. Among the firms that exited the sample, approximately 2.2\% disappeared and approximately 7.7\% stopped collaborating.

2 The definition of a "Catalan firm" is provided in the Appendix.

${ }^{3}$ Source: IDESCAT statistics, INE.

6 - IESE Business School-University of Navarra
} 
Table 1

Descriptive statistics, total sample.

\begin{tabular}{|c|c|c|c|c|c|c|c|c|c|c|}
\hline & & 1991 & 1992 & 1993 & 1994 & 1995 & 1996 & 1997 & 1998 & \\
\hline \multirow[t]{7}{*}{$\begin{array}{l}\text { Total } \\
\text { sample }\end{array}$} & $\begin{array}{l}\text { Number of } \\
\text { observations }\end{array}$ & 2058 & 1806 & 1744 & 1763 & 1605 & 1649 & 1830 & 1672 & \\
\hline & $\%$ of exporting firms & 51.3 & 54.0 & 53.0 & 57.3 & 60.8 & 60.8 & 62.8 & 64.8 & \\
\hline & $\%$ of importing firms & 53.2 & 54.3 & 54.2 & 59.3 & 61.1 & 61.0 & 62.2 & 63.9 & \\
\hline & $\begin{array}{l}\text { \% of product } \\
\text { innovators }\end{array}$ & 27.5 & 27.3 & 27.1 & 28.0 & 26.3 & 27.1 & 28.0 & 27.8 & \\
\hline & $\begin{array}{l}\text { \% of process } \\
\text { innovators }\end{array}$ & 36.6 & 33.9 & 34.5 & 35.7 & 33.8 & 33.6 & 36.1 & 38.0 & \\
\hline & $\begin{array}{l}\text { Value added per } \\
\text { employee, thousands } \\
\text { of Euros }\end{array}$ & 35.929 & 36.151 & 32.086 & 33.637 & 40.521 & 38.576 & 36.326 & 38.705 & \\
\hline & & 1991 & 1992 & 1993 & 1994 & 1995 & 1996 & 1997 & 1998 & \\
\hline \multirow[t]{7}{*}{$\begin{array}{l}\text { Catalan } \\
\text { firms }\end{array}$} & $\begin{array}{l}\text { Number of } \\
\text { observations }\end{array}$ & 532 & 446 & 436 & 445 & 413 & 406 & 403 & 365 & \\
\hline & $\%$ of exporting firms & 59.3 & 63.9 & 62.1 & 65.6 & 68.2 & 70.1 & 72.7 & 73.1 & \\
\hline & $\%$ of importing firms & 62.9 & 66.0 & 66.1 & 69.4 & 71.6 & 70.9 & 71.9 & 71.7 & \\
\hline & $\begin{array}{l}\text { \% of product } \\
\text { innovators }\end{array}$ & 30.0 & 29.1 & 33.6 & 33.7 & 31.4 & 30.5 & 30.0 & 34.5 & \\
\hline & $\begin{array}{l}\% \text { of process } \\
\text { innovators }\end{array}$ & 38.7 & 36.3 & 40.0 & 42.6 & 40.9 & 37.1 & 38.9 & 43.2 & \\
\hline & $\begin{array}{l}\text { Value added per } \\
\text { employee, thousands } \\
\text { of Euros }\end{array}$ & 38.277 & 37.802 & 33.716 & 36.906 & 41.737 & 42.908 & 41.000 & 44.234 & \\
\hline & & 1999 & 2000 & 2001 & 2002 & 2003 & 2004 & 2005 & 2006 & Total \\
\hline \multirow[t]{7}{*}{$\begin{array}{l}\text { Total } \\
\text { sample }\end{array}$} & $\begin{array}{l}\text { Number of } \\
\text { observations }\end{array}$ & 1670 & 1820 & 1669 & 1667 & 1345 & 1344 & 1877 & 1962 & 29665 \\
\hline & $\%$ of exporting firms & 63.7 & 65.7 & 65.7 & 64.7 & 64.7 & 64.8 & 62.6 & 62.5 & 60.0 \\
\hline & $\%$ of importing firms & 64.6 & 65.1 & 65.7 & 65.9 & 65.7 & 65.6 & 63.8 & 63.0 & 60.7 \\
\hline & $\begin{array}{l}\% \text { of product } \\
\text { innovators }\end{array}$ & 28.3 & 29.7 & 23.9 & 24.1 & 20.0 & 21.9 & 22.3 & 20.7 & 25.2 \\
\hline & $\begin{array}{l}\% \text { of process } \\
\text { innovators }\end{array}$ & 35.5 & 38.7 & 33.3 & 30.2 & 25.5 & 27.6 & 28.7 & 27.9 & 32.2 \\
\hline & $\begin{array}{l}\text { Value added per } \\
\text { employee, thousands } \\
\text { of Euros }\end{array}$ & 38.735 & 41.560 & 44.227 & 51.240 & 53.951 & 56.383 & 58.7 & 58.449 & 43.45 \\
\hline & & 1999 & 2000 & 2001 & 2002 & 2003 & 2004 & 2005 & 2006 & Total \\
\hline \multirow[t]{6}{*}{$\begin{array}{l}\text { Catalan } \\
\text { firms }\end{array}$} & $\begin{array}{l}\text { Number of } \\
\text { observations }\end{array}$ & 349 & 410 & 377 & 366 & 293 & 291 & 410 & 375 & 6844 \\
\hline & $\%$ of exporting firms & 72.4 & 74.6 & 74.5 & 74.0 & 74.4 & 74.2 & 73.6 & 76.8 & 68.8 \\
\hline & $\%$ of importing firms & 72.2 & 74.3 & 75.0 & 75.6 & 75.0 & 74.9 & 73.1 & 74.4 & 70.1 \\
\hline & $\begin{array}{l}\text { \% of product } \\
\text { innovators }\end{array}$ & 34.0 & 37.7 & 32.8 & 32.5 & 27.6 & 28.5 & 29.0 & 27.4 & 30.8 \\
\hline & $\begin{array}{l}\% \text { of process } \\
\text { innovators }\end{array}$ & 41.2 & 45.6 & 38.1 & 34.6 & 29.6 & 31.6 & 34.1 & 37.3 & 37.0 \\
\hline & $\begin{array}{l}\text { Value added per } \\
\text { employee, thousands } \\
\text { of Euros }\end{array}$ & 44.800 & 47.726 & 51.297 & 60.988 & 61.090 & 67.546 & 65.855 & 73.554 & 49.340 \\
\hline
\end{tabular}




\section{Figure 1}

\section{Export and Import volumes in Catalan economy 1994-2006, by sector}
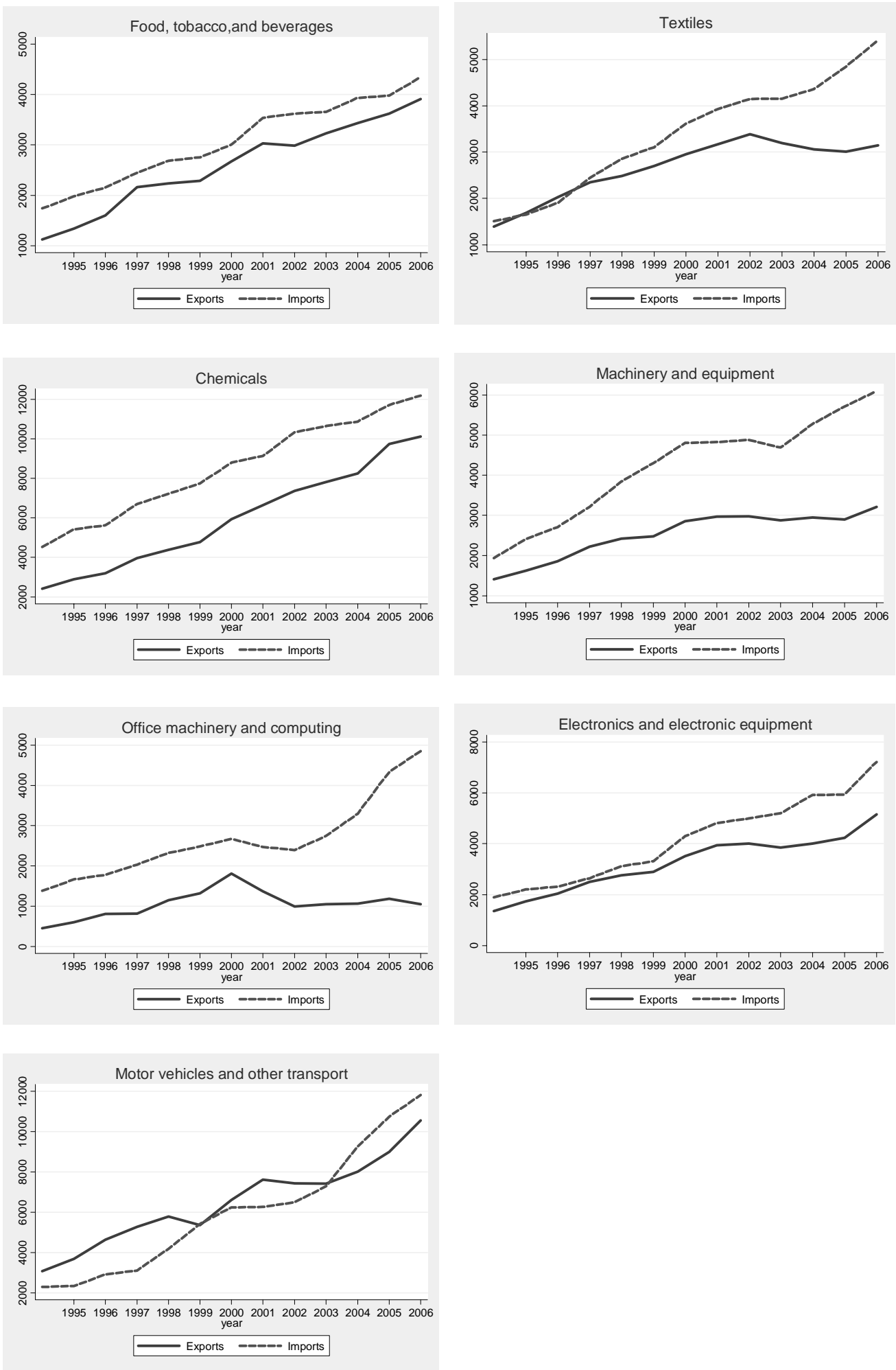
Table 2 summarizes the information on \% of exporting, importing and innovating firms for Catalan SMEs by sector. We compare two time periods: 1990-1999 versus 2000-2006. The results show the increase in the number of exporters, importers and the level of value added per employee in Textiles, Food tobacco and beverages, Chemicals, Machinery and equipment, and Office machinery and computing sectors. In Electronics and electronic equipment and Motor vehicles sectors the average percentage of importing firms has slightly decreased.

Table 2

Descriptive statistics, Catalan SMEs, by sector.

\begin{tabular}{|c|c|c|c|}
\hline Sector & Period averages & 1990-1999 & $2000-2006$ \\
\hline \multirow[t]{5}{*}{ Textiles } & $\%$ of exporters & 41.2 & 53.7 \\
\hline & $\%$ of importers & 52.2 & 65.7 \\
\hline & $\%$ of product innovators & 20.2 & 22.5 \\
\hline & $\%$ of process innovators & 27.1 & 22.5 \\
\hline & $\begin{array}{l}\text { Labor productivity (value added per } \\
\text { employee), thousands of Euros }\end{array}$ & 26.311 & 36.476 \\
\hline \multirow{5}{*}{$\begin{array}{l}\text { Food, tobacco and } \\
\text { beverages }\end{array}$} & $\%$ of exporters & 42.5 & 60.7 \\
\hline & $\%$ of importers & 34.3 & 48.1 \\
\hline & $\%$ of product innovators & 13.8 & 12.6 \\
\hline & $\%$ of process innovators & 24.1 & 18.9 \\
\hline & $\begin{array}{l}\text { Labor productivity (value added per } \\
\text { employee), thousands of Euros }\end{array}$ & 32.138 & 56.089 \\
\hline \multirow[t]{5}{*}{ Chemicals } & $\%$ of exporters & 58.1 & 82.4 \\
\hline & $\%$ of importers & 72.0 & 96.4 \\
\hline & $\%$ of product innovators & 42.7 & 52.6 \\
\hline & $\%$ of process innovators & 38.6 & 46.4 \\
\hline & $\begin{array}{l}\text { Labor productivity (value added per } \\
\text { employee), thousands of Euros }\end{array}$ & 45.296 & 85.742 \\
\hline \multirow{5}{*}{$\begin{array}{l}\text { Machinery and } \\
\text { equipment }\end{array}$} & $\%$ of exporters & 60.3 & 63.5 \\
\hline & $\%$ of importers & 53.1 & 64.7 \\
\hline & $\%$ of product innovators & 32.6 & 30.0 \\
\hline & $\%$ of process innovators & 27.3 & 22.5 \\
\hline & $\begin{array}{l}\text { Labor productivity (value added per } \\
\text { employee), thousands of Euros }\end{array}$ & 35.099 & 51.963 \\
\hline \multirow{5}{*}{$\begin{array}{l}\text { Office machinery and } \\
\text { computing }\end{array}$} & $\%$ of exporters & 64.0 & 88.2 \\
\hline & $\%$ of importers & 78.6 & 94.1 \\
\hline & $\%$ of product innovators & 46.6 & 47.0 \\
\hline & $\%$ of process innovators & 18.6 & 8.8 \\
\hline & $\begin{array}{l}\text { Labor productivity (value added per } \\
\text { employee), thousands of Euros }\end{array}$ & 37.770 & 71.824 \\
\hline \multirow{5}{*}{$\begin{array}{l}\text { Electronics and } \\
\text { electronic equipment }\end{array}$} & $\%$ of exporters & 65.0 & 74.1 \\
\hline & $\%$ of importers & 76.8 & 67.2 \\
\hline & $\%$ of product innovators & 41.8 & 22.4 \\
\hline & $\%$ of process innovators & 35.6 & 31.0 \\
\hline & $\begin{array}{l}\text { Labor productivity (value added per } \\
\text { employee), thousands of Euros }\end{array}$ & 43.738 & 52.972 \\
\hline \multirow{5}{*}{$\begin{array}{l}\text { Motor vehicles and } \\
\text { other transport } \\
\text { equipment }\end{array}$} & $\%$ of exporters & 57.3 & 62.5 \\
\hline & $\%$ of importers & 65.3 & 59.3 \\
\hline & $\%$ of product innovators & 18.6 & 17.1 \\
\hline & $\%$ of process innovators & 33.3 & 28.1 \\
\hline & $\begin{array}{l}\text { Labor productivity (value added per } \\
\text { employee), thousands of Euros }\end{array}$ & 35.683 & 38.771 \\
\hline \multirow[t]{5}{*}{ All sectors } & $\%$ of exporters & 49.8 & 61.7 \\
\hline & $\%$ of importers & 52.1 & 61.9 \\
\hline & $\%$ of product innovators & 24.5 & 22.1 \\
\hline & $\%$ of process innovators & 29.1 & 26.9 \\
\hline & $\begin{array}{l}\text { Labor productivity (value added per } \\
\text { employee), thousands of Euros }\end{array}$ & 33.122 & 47.674 \\
\hline
\end{tabular}


Table 3 compares the means of value added per employee for these sectors over 1990-1999 and 2000-2006. Electronics and electronic equipment and Motor vehicle and other transport sectors, which showed the decrease in the \% of importing firms, also show the lowest \% increase in the productivity of productivity measured as value added per employee.

\section{Table 3}

Comparison of the means of labor productivity for different sectors, 1990-1999 versus 2000-2006

\begin{tabular}{|c|c|c|c|c|c|c|}
\hline & \multicolumn{2}{|c|}{ Number of firm-year obs. } & \multicolumn{2}{|c|}{$\begin{array}{l}\text { Labor productivity level } \\
\text { increase, } \%\end{array}$} & \multicolumn{2}{|c|}{$\begin{array}{l}\text { Labor productivity } \\
\text { level increase }{ }^{4}, \%\end{array}$} \\
\hline & 1990-1999 & $2000-2006$ & $\%$ (nominal) & $\mathrm{P}$-value & $\%$ (deflated) & $\mathrm{P}$-value \\
\hline Textiles & 264 & 527 & $38 \%$ & 0.000 & $24 \%$ & 0.000 \\
\hline Food, tobacco and beverages & 193 & 79 & $74 \%$ & 0.015 & $38 \%$ & 0.120 \\
\hline Chemicals & 114 & 211 & $89 \%$ & 0.000 & $56 \%$ & 0.000 \\
\hline Machinery and equipment & 173 & 294 & $48 \%$ & 0.000 & $25 \%$ & 0.000 \\
\hline Office machinery and computing & 34 & 74 & $90 \%$ & 0.004 & $139 \%$ & 0.004 \\
\hline Electronics and electronic equipment & 159 & 85 & $21 \%$ & 0.013 & $11 \%$ & 0.120 \\
\hline Motor vehicles and other transport & 74 & 64 & $9 \%$ & 0.216 & $-8 \%$ & 0.800 \\
\hline Total manufacturing sector & 2728 & 1522 & $44 \%$ & 0.000 & $23 \%$ & 0.000 \\
\hline
\end{tabular}

Figure 2 illustrates the results in Table 4 and depicts the labor productivity distributions of these sectors across two time periods 1990-1999 and 2000-2006.

\footnotetext{
${ }^{4}$ The productivity level is deflated by a producer price index defined at the two-digit NACE industry level. Source: Instituto Nacional de Estadística de España (www.ine.es).
} 


\section{Figure 2}

Evolution of labor productivity levels for Catalan SMEs across 1990-2006.

\section{Textiles}

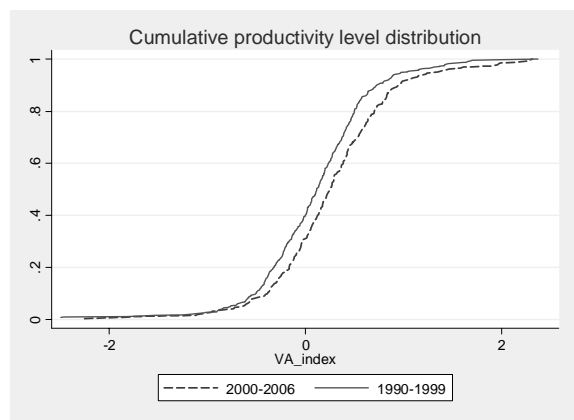

Machinery and equipment

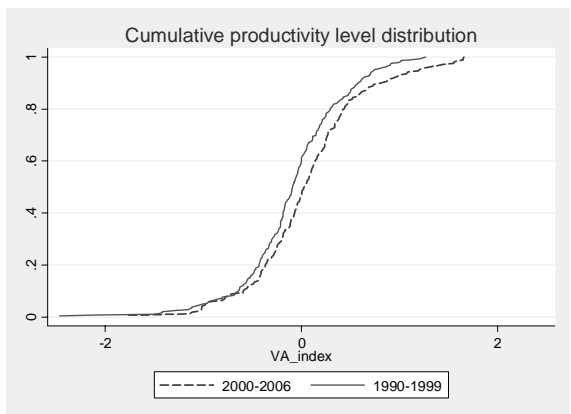

Food tobacco and beverages

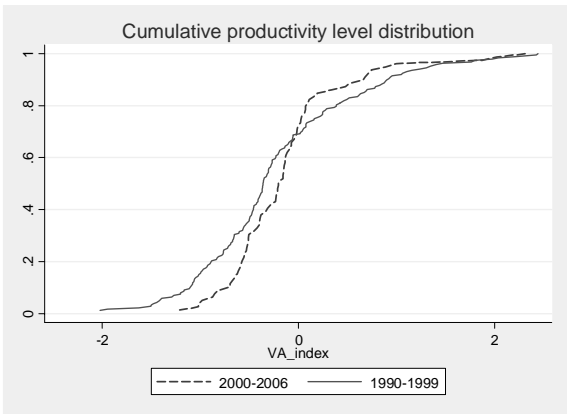

Motor vehicles and other transport

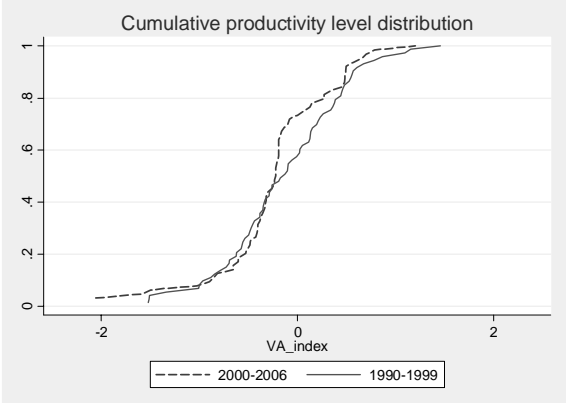

Office machinery and computing

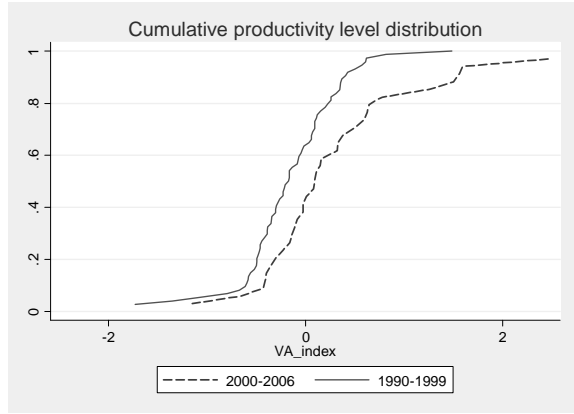

Electronics and electronic equipment

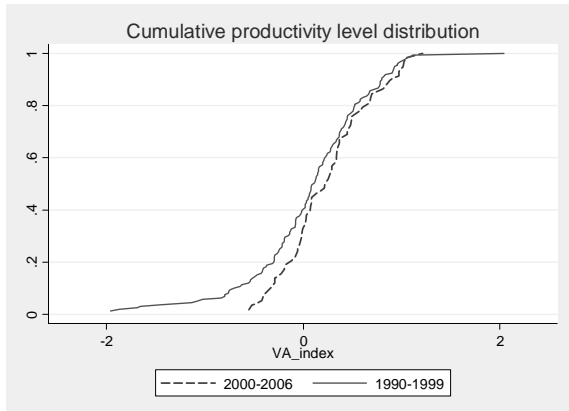

Chemicals

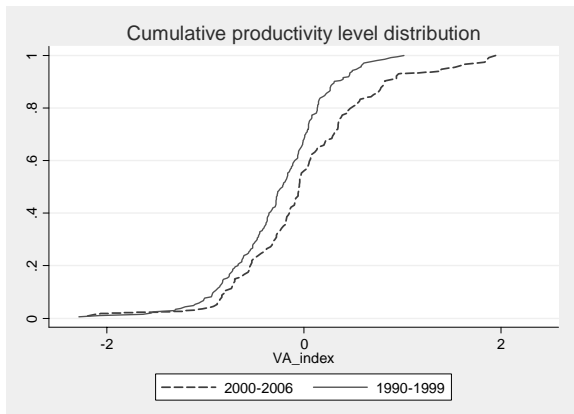


The visual comparison of productivity distributions shows that the productivity levels have improved in Textiles, Office machinery and computing, Machinery and equipment, Electronics and electronic equipment, and Chemicals sectors. The productivity distribution for 2000-2006 stochastically dominates the distribution for 1990-1999. In two other sectors, Food, tobacco and beverages and Motor vehicles and other transport, we do not observe such generalized productivity improvements. The figures seem to suggest that, while in Food, Tobacco and Beverages the low productivity firms improved their productivity, in Motor Vehicles and other Transport there is no clear pattern.

In the following tables we now attempt to connect the productivity enhancing investments with exporting. Tables 4A-B report the correlation coefficients for import, export, and innovation activities and value added per employee as our productivity measure. We observe positive correlation between Value Added and import, as well as export activities with the magnitude of the coefficient being very similar. Innovation activities, both product and process innovations, also show positive association with value added, with the correlation coefficient of product innovation being slightly larger than that of process innovation.

Table 4A

Correlation Table. Value added per employee and import/export/innovation activities, Catalan SMEs, 1990-2006

\begin{tabular}{|l|c|c|c|c|c|}
\hline & $\begin{array}{c}\text { Value added per } \\
\text { employee }\end{array}$ & Import & Export & $\begin{array}{c}\text { Product } \\
\text { innovation }\end{array}$ & $\begin{array}{c}\text { Process } \\
\text { innovation }\end{array}$ \\
\hline $\begin{array}{l}\text { Value added per } \\
\text { employee }\end{array}$ & 1.000 & & & & \\
\hline Import & 0.227 & 1.000 & & & \\
\hline Export & 0.229 & 0.494 & 1.000 & & \\
\hline Product innovation & 0.089 & 0.202 & 0.210 & 1.000 & \\
\hline Process innovation & 0.072 & 0.097 & 0.120 & 0.280 & 1.000 \\
\hline
\end{tabular}

\section{Table 4B}

Correlation Table. Value added per employee and import/export volumes, Catalan SMEs, 19902006

\begin{tabular}{|l|c|c|c|c|c|}
\hline & $\begin{array}{c}\text { Value added per } \\
\text { employee }\end{array}$ & $\begin{array}{c}\text { Import } \\
\text { volume }\end{array}$ & $\begin{array}{c}\text { Import } \\
\text { intensity }\end{array}$ & $\begin{array}{c}\text { Export } \\
\text { volume }\end{array}$ & $\begin{array}{c}\text { Export } \\
\text { intensity }\end{array}$ \\
\hline $\begin{array}{l}\text { Value added per } \\
\text { employee }\end{array}$ & 1.000 & & & & \\
\hline Import volume & 0.174 & 1.000 & & & \\
\hline Import intensity & 0.168 & 0.501 & 1.000 & & \\
\hline Export volume & 0.227 & 0.641 & 0.356 & 1.000 & \\
\hline Export intensity & 0.169 & 0.224 & 0.345 & 0.544 & 1.000 \\
\hline
\end{tabular}

Overall, the results suggest a positive association between firm productivity measured by value added and importing/exporting activities.

Finally, Table 5 reports the percentage of exporting firms and added-value of firms for different combinations of innovation-import activities for Catalan SMEs. We observe the highest number of exporters (84.9\%) in the subsample of firms that also perform import and innovation activities. Moreover, the results show that firms with import and innovation activities also have 
the highest level of value added per employee. Interestingly, however, the biggest jump in export active firms and increase in value added per worker happens for the import activity. This suggests that import activities might be highly correlated with productivity enhancing decisions for Catalan firms. Overall this last table hints at a strong complementarity between these different decisions of the firm. In what follows we will examine a sequential link between these activities and evaluate the effect of combining these activities on firm productivity.

Table 5

Imports, innovation, and exports. Catalan SMEs 1990-2006.

\begin{tabular}{|c|c|c|}
\hline & No Innovation & Innovation \\
\hline No Imports & $\begin{array}{l}\text { Observations: } 1337 \\
\text { Exporters: } 22.4 \% \\
\text { Value added per employee: } 28.311\end{array}$ & $\begin{array}{l}\text { Observations: } 575 \\
\text { Exporters: } 36 \% \\
\text { Value added per employee: } 30.836\end{array}$ \\
\hline \multirow[t]{2}{*}{ Imports } & $\begin{array}{l}\text { Observations: } 1247 \\
\text { Exporters: } 70.8 \% \\
\text { Value added per employee: } 43.411\end{array}$ & $\begin{array}{l}\text { Observations: } 1151 \\
\text { Exporters: } 81.6 \% \\
\text { Value added per employee: } 48.196\end{array}$ \\
\hline & No Product Innovation & Product Innovation \\
\hline No Imports & $\begin{array}{l}\text { Observations: } 1645 \\
\text { Exporters: } 24.4 \% \\
\text { Value added per employee: } 28.938\end{array}$ & $\begin{array}{l}\text { Observations: } 267 \\
\text { Exporters: } 39.3 \% \\
\text { Value added per employee: } 29.894\end{array}$ \\
\hline Imports & $\begin{array}{l}\text { Observations: } 1643 \\
\text { Exporters: } 71.9 \% \\
\text { Value added per employee: } 43.979\end{array}$ & $\begin{array}{l}\text { Observations: } 755 \\
\text { Exporters: } 84.9 \% \\
\text { Value added per employee: } 49.456\end{array}$ \\
\hline
\end{tabular}

\section{Empirical Methodology}

Up to now we have shown that imports, innovation, exports and productivity are strongly correlated. We proceed by showing how export behavior is affected by imports and innovation in a random probit regression, and we also use a random effects model to examine the determinants of the decisions to import and innovate. Next, we attempt to connect importing, innovating and exporting behavior to the productivity levels of performing versus nonperforming firms (i.e., exporters versus non-exporters, importers versus non-importers, innovators versus non-innovators) in order to show the strong complementarity suggested by the descriptive statistics. We first use the graphical description of the productivity distributions across 1990-2006. We proceed by conducting a number of formal tests. We first compare the means of labor productivity in these sub samples and then compare the productivity distributions themselves, using a Kolmogorov-Smirnov equality of distributions test. ${ }^{5}$

Variable definitions. We define exporters as firms exporting, i.e., with positive sales outside of Spain, in the current year. Non-exporters are those firms that did not perform exports in the current year. Importers are firms that have performed importing activities in the current year. Innovation activity is measured in several ways. We distinguish between innovating in product and in process, using two dummies that indicate whether a firm carried out a product or a process

\footnotetext{
${ }^{5}$ The explanation of the test can be found in the Appendix.
} 
innovation, respectively. ${ }^{6}$ Furthermore, we employ a dummy variable that indicates whether a firm has performed any innovation activity (either product or process). To measure firm productivity, we construct an index of labor productivity calculated as value added per employee for each firm using a multilateral index developed by Caves et al. (1982) and extended by Good et al. (1997). The Appendix provides a careful description of each of the variables.

\section{Results}

\subsection{Regression Results}

Tables 6-9 report the results of random probit regressions which model the decisions to export, innovate (product and process) and import respectively. We seem to find a sequentiality between these productivity enhancing activities where imports affect product innovation and imports and product innovation in turn affect exporting.

\section{Table 6}

The decision to export, Catalan SMEs, 1990-2006

\begin{tabular}{|c|c|c|}
\hline & Random effects probit & Marginal effects \\
\hline Export (t-1) & $\begin{array}{r}1.987^{\star \star \star} \\
(0.111) \\
\end{array}$ & $0.663^{\star \star \star}$ \\
\hline Export (t-2) & $\begin{array}{r}0.746^{* \star *} \\
(0.114) \\
\end{array}$ & $0.275^{\star \star \star}$ \\
\hline Import (t-1) & $\begin{array}{l}0.255^{\star \star} \\
(0.130) \\
\end{array}$ & $0.095^{\star \star}$ \\
\hline Import (t-2) & $\begin{array}{r}-0.012 \\
(0.131) \\
\end{array}$ & -0.004 \\
\hline Product innovation (t-1) & $\begin{array}{r}0.255^{\star *} \\
(0.106)\end{array}$ & $0.092^{\star \star}$ \\
\hline Process innovation (t-1) & $\begin{array}{r}0.128 \\
(0.094) \\
\end{array}$ & 0.047 \\
\hline Labor productivity (t-1) & $\begin{array}{r}0.358^{\star * *} \\
(0.069) \\
\end{array}$ & $0.133^{\star \star \star}$ \\
\hline Size & $\begin{array}{r}0.249^{* * *} \\
(0.056)\end{array}$ & $0.093^{* * *}$ \\
\hline Foreign capital & $\begin{array}{r}-0.030 \\
(0.153) \\
\end{array}$ & -0.011 \\
\hline Intercept & $-4.630^{* * *}$ & \\
\hline $\begin{array}{l}\text { Number of observations: } 2498 \\
*, * *, * * * \text { are significantly different from zero at the } 10 \% \text {, } \\
5 \% \text { or } 1 \% \text { level respectively. } \\
\text { Industry and year fixed effects are included }\end{array}$ & & \\
\hline
\end{tabular}

As shown in the existing literature, exporting is extremely persistent. The fact that a firm is exporting in one year increases the probability that the firm will be exporting in the next year by $66 \%$. Importing and product innovation increase the probability of exporting the next year

\footnotetext{
${ }^{6}$ These dummies are defined in two different ways. First, we consider product and process innovations that are not exclusive, i.e., if a firm has product innovation it may or may not have process innovation at the same time. Second, we define them exclusively, i.e., product innovation means the firm had a product innovation in year t-1, but not a process innovation in year t-1. Process innovation is defined in an analogue way; see Appendix.
} 
by about 9\%. Interestingly, process innovation does not seem to affect the decision to start exporting. Firms that generate process innovations might already be active in the export market, or process innovations happen later in the product life cycle so that international markets are already much more competitive and, as a result, a process innovation does not trigger entry into the export market.

\section{Table 7}

The decision to innovate in product, Catalan SMEs, 1990-2006

\begin{tabular}{|c|c|c|}
\hline & Random effects probit & Marginal effects \\
\hline Export $(\mathrm{t}-1)$ & $\begin{array}{r}0.163 \\
(0.102)\end{array}$ & 0.035 \\
\hline Import (t-1) & $\begin{array}{c}0.229 \text { ** } \\
(0.103)\end{array}$ & 0.048 \\
\hline Product innovation (t-1) & $\begin{array}{r}1.054^{* * *} \\
(0.089)\end{array}$ & 0.290 \\
\hline Labor productivity (t-1) & $\begin{array}{r}0.065 \\
(0.078) \\
\end{array}$ & 0.014 \\
\hline Size & $\begin{array}{r}0.161^{\star \star \star} \\
(0.060) \\
\end{array}$ & 0.034 \\
\hline Foreign capital & $\begin{array}{r}-0.164 \\
(0.142) \\
\end{array}$ & -0.033 \\
\hline Intercept & $\begin{array}{r}-2.445^{\star *} \\
(0.954) \\
\end{array}$ & \\
\hline $\begin{array}{l}\text { Number of observations: } 2498 \\
*, * *,{ }^{* *} \text { are significantly different from zero at the } 10 \% \text {, } \\
5 \% \text { or } 1 \% \text { level respectively. } \\
\text { Industry and year fixed effects are included }\end{array}$ & & \\
\hline
\end{tabular}

Table 8

The decision to innovate in process, Catalan SMEs, 1990-2006

\begin{tabular}{|c|c|c|}
\hline & Random effects probit & Marginal effects \\
\hline Export (t-1) & $\begin{array}{r}0.083 \\
(0.082)\end{array}$ & 0.026 \\
\hline Import (t-1) & $\begin{array}{r}0.016 \\
(0.083)\end{array}$ & 0.005 \\
\hline Process innovation (t-1) & $\begin{array}{r}0.998^{\star \star \star} \\
(0.073)\end{array}$ & $0.347^{* \star \star}$ \\
\hline Labor productivity (t-1) & $\begin{array}{r}0.041 \\
(0.061) \\
\end{array}$ & 0.013 \\
\hline Size & $\begin{array}{r}0.215^{\star \star \star} \\
(0.049)\end{array}$ & $0.069^{\star \star \star}$ \\
\hline Foreign capital & $\begin{array}{r}-0.187 \\
(0.117)\end{array}$ & $-0.057^{\star}$ \\
\hline Intercept & $\begin{array}{r}-2.267^{* * *}(0.768) \\
\end{array}$ & \\
\hline $\begin{array}{l}\text { Number of observations: } 2498 \\
{ }^{*},{ }^{* *}{ }^{* * *} \text { are significantly different from zero at the } 10 \% \text {, } \\
5 \% \text { or } 1 \% \text { level respectively. } \\
\text { Industry and year fixed effects are included }\end{array}$ & & \\
\hline
\end{tabular}

When examining the innovation decisions of firms (Tables 7-8) we find that larger firms are more likely to innovate both in process and in product. However, import activity does seem to 
affect product innovation, but does not seem affect process innovation. Imports of higher quality inputs or of inputs with higher technological content might lead to product innovations rather than process innovations.

When looking at the import decision of the firm we find that neither exports nor innovation seem to affect this decision. On the contrary, past import behavior directly affects future import behavior. This result very much resembles the export persistence we found earlier.

\section{Table 9}

The decision to import, Catalan SMEs, 1990-2006

\begin{tabular}{|c|c|c|}
\hline & Random effects probit & Marginal effects \\
\hline Export (t-1) & $\begin{array}{r}0.191 \\
(0.129)\end{array}$ & 0.069 \\
\hline Export(t-2) & $\begin{array}{r}0.135 \\
(0.130) \\
\end{array}$ & 0.049 \\
\hline Import (t-1) & $\begin{array}{r}1.861^{\star * \star} \\
(0.102) \\
\end{array}$ & $0.625^{\star \star \star}$ \\
\hline Import(t-2) & $\begin{array}{r}0.609^{\star * *} \\
(0.104) \\
\end{array}$ & $0.221^{\star * \star}$ \\
\hline Product innovation (t-1) & $\begin{array}{r}-0.108 \\
(0.100) \\
\end{array}$ & -0.039 \\
\hline Process innovation (t-1) & $\begin{array}{r}0.019 \\
(0.089) \\
\end{array}$ & 0.007 \\
\hline Labor productivity (t-1) & $\begin{array}{r}0.325^{\star \star *} \\
(0.065) \\
\end{array}$ & $0.118^{\star \star \star}$ \\
\hline Size & $\begin{array}{r}0.252^{\star \star \star} \\
(0.052) \\
\end{array}$ & $0.091^{\star \star \star}$ \\
\hline Foreign capital & $\begin{array}{r}0.261 \\
(0.167) \\
\end{array}$ & $0.090^{*}$ \\
\hline Intercept & $\begin{array}{r}-4.079^{\star \star \star} \\
(1.101) \\
\end{array}$ & \\
\hline $\begin{array}{l}\text { Number of observations: } 2498 \\
{ }^{*}{ }^{* *},{ }^{* *} \text { are significantly different from zero at the } \\
10 \%, 5 \% \text { or } 1 \% \text { level respectively. } \\
\text { Industry and year fixed effects are included }\end{array}$ & & \\
\hline
\end{tabular}

As imports seem to affect product innovation but not process innovation, the next logical step is to ask what kind of product innovation we are talking about. The following tables (Tables $10 \mathrm{~A}-$ B) show that product innovation is related to different possible issues such as the incorporation of new materials, new components, new designs or new functions. All of these types of product innovations are highly correlated, but the most common product innovation seems to be the incorporation of a new design. It would be interesting to check the technological content of imports of the firms, but unfortunately this information is not available.

Table 10A

Type of product innovation for importers, 1990-2002, SMEs in Catalonia

\begin{tabular}{|l|c|}
\hline Type of product innovation & $\%$ of product innovations \\
\hline Incorporates new materials & $51.5 \%$ \\
\hline Incorporates new components or intermediate products & $49.3 \%$ \\
\hline Incorporates new design or presentation & $72.8 \%$ \\
\hline Incorporates new functions & $47.9 \%$ \\
\hline
\end{tabular}


Table 10B

Correlation between imports and different types of product innovation

\begin{tabular}{|l|c|c|c|c|c|}
\hline & $\mathbf{1}$ & $\mathbf{2}$ & $\mathbf{3}$ & $\mathbf{4}$ & $\mathbf{5}$ \\
\hline Import (1) & 1.000 & & & & \\
\hline New materials (2) & 0.1538 & 1.000 & & & \\
\hline $\begin{array}{l}\text { New components or } \\
\text { intermediate products (3) }\end{array}$ & 0.1555 & 0.6257 & 1.000 & & \\
\hline New design or presentation (4) & 0.1532 & 0.5828 & 0.5699 & 1.000 & \\
\hline New functions (5) & 0.1684 & 0.4605 & 0.4270 & 0.4400 & 1.000 \\
\hline
\end{tabular}

In conclusion, we seem to find an important sequentiality linking these different firm decisions. If confirmed, this would have important policy implications for where policy makers want to intervene in this process. One could intervene in the later export stage, as is often the case, but the question is whether, if firms are not importing high quality inputs or do not have access to a higher variety of inputs and as a result are less innovative, especially in developing product innovations, they can really be successful in the export market. We turn to this question next.

\subsection{Productivity Distributions Comparison}

In this final section we examine the distributions of "performers versus non-performers" in order to understand whether these different activities - importing, innovating and exporting explain part of the productivity levels of the firms. We start by examining the different activities in isolation. As argued in the introduction, there exists a large body of literature on the link between exports and productivity. Indeed, as shown in the first panel of Figure 3, exporting firms do have much higher productivity. The productivity distribution of exporting firms dominates that on non-exporters in a first order stochastic dominance sense, i.e., the cumulative distribution of the exporting firms lays below that of non-exporting firms. However, importing firms are also highly related to higher productivity firms (panel 2). Finally, innovation - both product and process - have a positive relation with productivity according to the graphs (panel 3-4). Table 11 tests all these relations and shows that there is indeed a significant correlation between the different activities and firm level productivity. Column 3 of Table 11 shows the difference in productivity at the mean of the distribution between performers (exporters or importers or innovators) and non-performers of the activity using our multilateral index explained in the Appendix. The significance of this difference in mean is tested in the next 2 columns. While all activities generate significant differences at the mean of the distribution, imports followed by exports seem to explain more of the firms' productivity level difference. The final columns of Table 11 test the significance of the productivity distribution of performers versus non-performers, as explained in detail in the Appendix. All activities taken independently do generate significantly different distributions between performers and non-performers. 
Figure 3

Comparison of labor productivity distributions of performers versus non-performers, Catalan SMEs, 1990-2006

Export

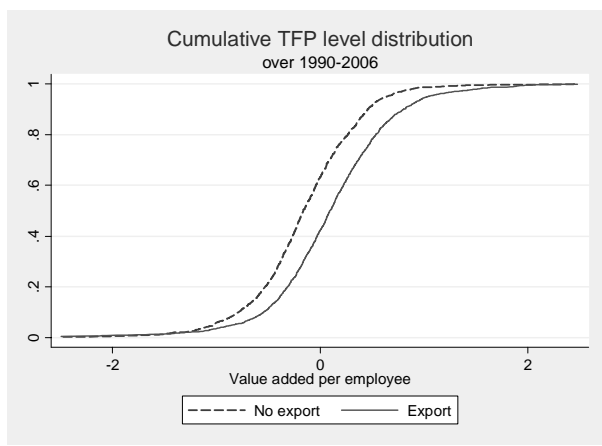

Product innovation

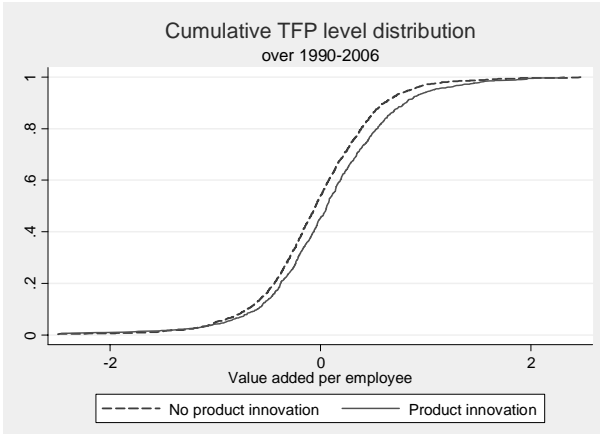

Import

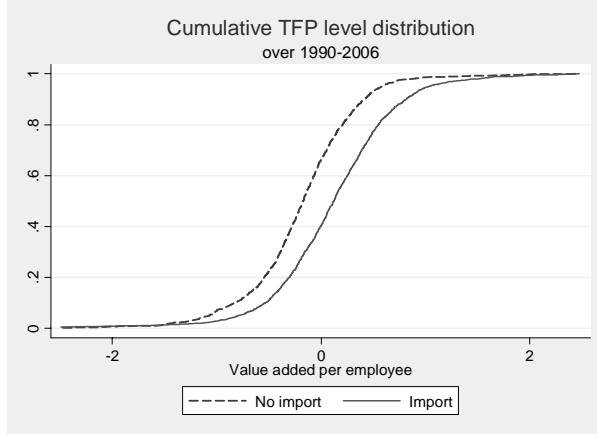

Process innovation

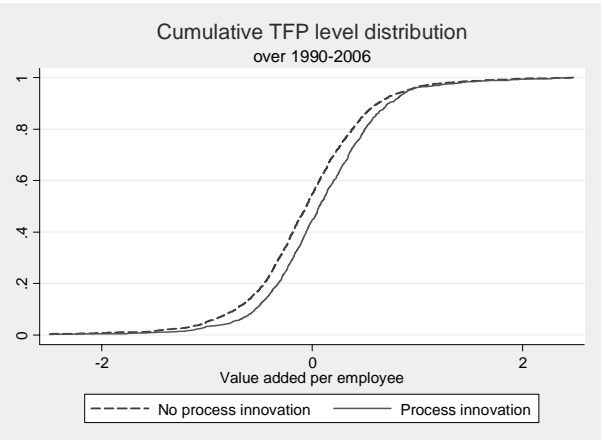

Table 11

Difference in labor productivity level distributions between importers/exporters/innovators and nonimporters/non-exporters/non-innovators, SMEs in Catalonia 1990-2006

\begin{tabular}{|c|c|c|c|c|c|c|c|c|c|}
\hline & \multicolumn{2}{|c|}{$\begin{array}{c}\text { Number of } \\
\text { firm-year obs. }\end{array}$} & \multirow[t]{2}{*}{$\begin{array}{l}\text { Differe } \\
\text { nce in } \\
\text { means }\end{array}$} & \multicolumn{2}{|c|}{$\begin{array}{c}\text { Mean (non- } \\
\text { performers)>mean } \\
\text { (performers) }\end{array}$} & \multicolumn{2}{|c|}{$\begin{array}{l}\text { K-S test for } \\
\text { equality of } \\
\text { distributions }\end{array}$} & \multicolumn{2}{|c|}{$\begin{array}{l}\text { Difference in } \\
\text { favor of } \\
\text { performers }\end{array}$} \\
\hline & 1 & 0 & & t-statistic & $\mathrm{P}$-value & $\mathrm{D}$ & P-value & $\mathrm{D}$ & P-value \\
\hline Export & 2298 & 1931 & .258 & -14.192 & 0.000 & 0.215 & 0.000 & -0.003 & 0.972 \\
\hline Import & 2359 & 1870 & .3067 & -16.953 & 0.000 & 0.261 & 0.000 & -0.003 & 0.975 \\
\hline Innovation & 1695 & 2535 & .125 & -6.684 & 0.000 & 0.114 & 0.000 & -0.002 & 0.992 \\
\hline $\begin{array}{l}\text { Product innovation } \\
\text { excl }\end{array}$ & 491 & 2535 & .067 & -2.243 & 0.012 & 0.094 & 0.001 & -0.008 & 0.943 \\
\hline $\begin{array}{l}\text { Process innovation } \\
\text { excl }\end{array}$ & 690 & 2535 & .112 & -4.506 & 0.000 & 0.110 & 0.000 & -0.015 & 0.765 \\
\hline Product innovation & 1005 & 3225 & .110 & -5.0988 & 0.000 & 0.096 & 0.000 & -0.005 & 0.959 \\
\hline Process innovation & 1204 & 3026 & .138 & -6.788 & 0.000 & 0.111 & 0.000 & -0.000 & 0.999 \\
\hline
\end{tabular}

Next, we condition on imports. As we found in the previous section, imports seem to drive both innovation and exports. If imports explained all the productivity differentials, then controlling for imports would take away any correlation of innovation or exports with productivity. If on the other 
hand imports, innovation and exports are complementary, we should find that adding these activities increases the marginal return of the other activities. Our results in Figure 4 seem to suggest that imports and product innovation are indeed strongly correlated. For importing firms there is no additional productivity differential between product innovators or no product innovators. For exports, however, we do find complementarity between the activities. Nonimporting firms that export have higher productivity than non-exporting firms that also do not import. But importing firms that also export add more to their productivity than non-exporting, but importing firms. Table 12 reports again the differences at the mean and their significance. In addition, Table 12 reports the results of the test for the equality of means and Kolmogorov-Smirnov test for the equality of distributions, showing that the distribution of importing firms that innovate in product does not differ statistically from the distribution of importing firms that do not innovate in product. All other distributions between performers and non-performers do differ significantly, but the importing exporters seem to clearly dominate the productivity distribution. 


\section{Figure 4}

Comparison of labor productivity distributions conditional on previous import status of a firm for product innovation, process innovation, and exports, Catalan SMEs, 1990-2006

\section{Product innovation conditional on imports}

Import ( $\mathrm{t}-1)=1$

Cumulative productivity level distribution over 1990-2006

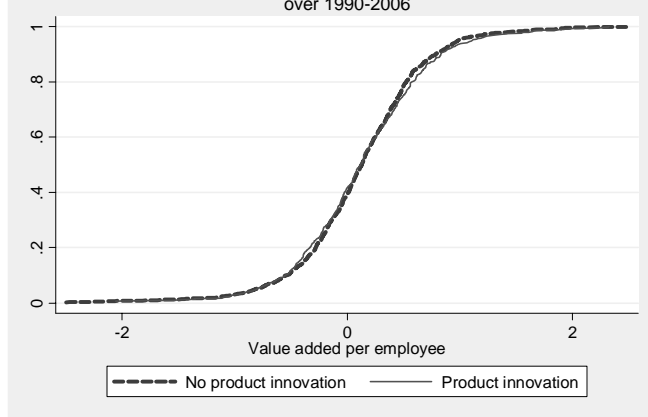

Import (t-1) $=0$

Cumulative productivity level distribution over 1990-2006

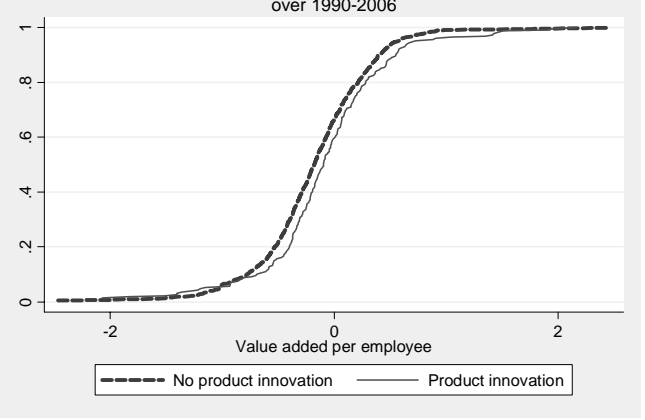

Process innovation conditional on import

Import (t-1)=1

Cumulative productivity level distribution over 1990-2006

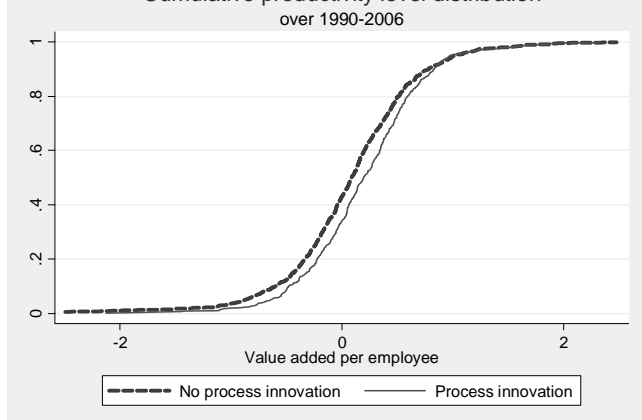

Import (t-1) $=0$

Cumulative productivity level distribution over 1990-2006

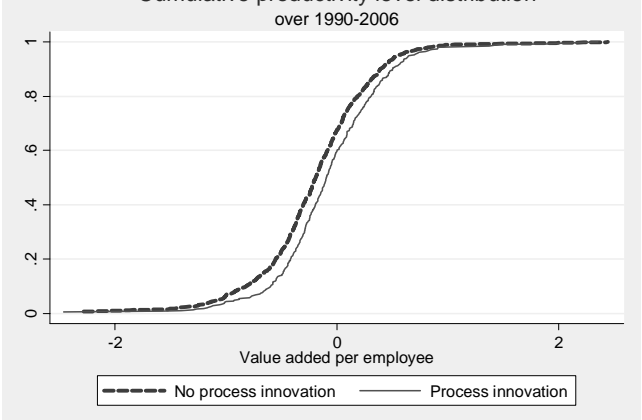

\section{Exports conditional on import}

Import $(\mathrm{t}-1)=1$

Cumulative productivity level distribution over 1990-2006

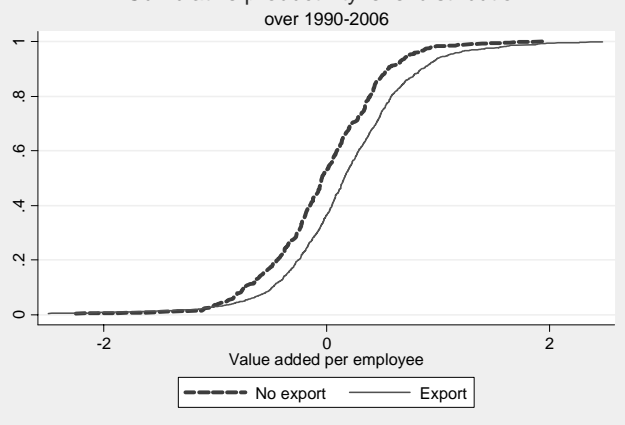

Import (t-1) $=0$

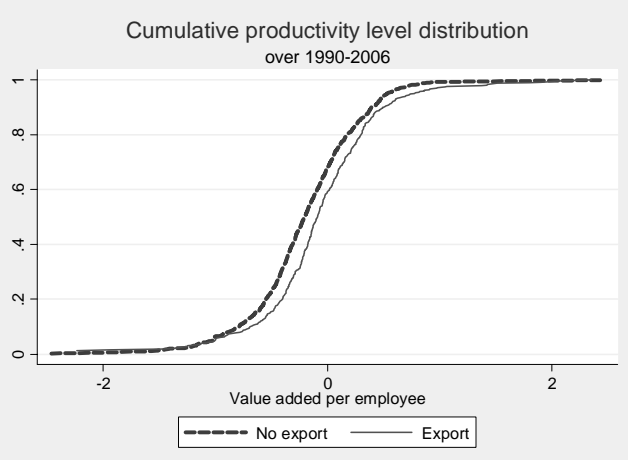


Table 12

Difference in labor productivity distributions between performers and non-performers conditional on firm import status in a previous year, SMEs in Catalonia 1990-2006

\begin{tabular}{|c|c|c|c|c|c|c|c|c|c|}
\hline & \multicolumn{2}{|c|}{$\begin{array}{l}\text { Number of firm- } \\
\text { year obs. }\end{array}$} & \multirow[t]{2}{*}{$\begin{array}{l}\text { Difference } \\
\text { in means }\end{array}$} & \multicolumn{2}{|c|}{$\begin{array}{c}\text { Mean (non- } \\
\text { innovators)> mean } \\
\text { (innovators) }\end{array}$} & \multicolumn{2}{|c|}{$\begin{array}{l}\text { K-S test for } \\
\text { equality of } \\
\text { distributions }\end{array}$} & \multicolumn{2}{|c|}{$\begin{array}{l}\text { Difference in favor } \\
\text { of innovators }\end{array}$} \\
\hline & 1 & 0 & & t-statistic & $\mathrm{P}$-value & D & $\mathrm{P}$-value & D & $\mathrm{P}$-value \\
\hline \multicolumn{10}{|l|}{ Import=1 } \\
\hline Innovation & 1001 & 1056 & .035 & -1.322 & 0.093 & 0.053 & 0.091 & -0.020 & 0.655 \\
\hline $\begin{array}{l}\text { Product innovation } \\
\text { excl }\end{array}$ & 322 & 1056 & -.100 & 2.512 & 0.993 & 0.095 & 0.018 & -0.095 & 0.011 \\
\hline $\begin{array}{l}\text { Process innovation } \\
\text { excl }\end{array}$ & 343 & 1056 & .054 & -1.492 & 0.067 & 0.121 & 0.001 & -0.050 & 0.271 \\
\hline Product innovation & 658 & 1399 & .011 & -0.4016 & 0.344 & 0.039 & 0.463 & -0.035 & 0.324 \\
\hline Process innovation & 679 & 1378 & .122 & -4.3643 & 0.000 & 0.122 & 0.000 & -0.008 & 0.933 \\
\hline Export & 1591 & 466 & .204 & -6.519 & 0.000 & 0.174 & 0.000 & -0.009 & 0.934 \\
\hline \multicolumn{10}{|l|}{ Import=0 } \\
\hline Innovation & 483 & 1104 & .092 & -3.076 & 0.001 & 0.097 & 0.003 & -0.002 & 0.997 \\
\hline $\begin{array}{l}\text { Product innovation } \\
\text { excl }\end{array}$ & 110 & 1104 & .023 & -0.431 & 0.333 & 0.121 & 0.083 & -0.031 & 0.815 \\
\hline $\begin{array}{l}\text { Process innovation } \\
\text { excl }\end{array}$ & 255 & 1104 & .077 & -2.093 & 0.018 & 0.093 & 0.046 & -0.024 & 0.780 \\
\hline Product innovation & 228 & 1359 & .094 & -2.392 & 0.008 & 0.104 & 0.023 & -0.020 & 0.852 \\
\hline Process innovation & 373 & 1214 & .109 & -3.389 & 0.000 & 0.094 & 0.010 & -0.001 & 0.998 \\
\hline Export & 465 & 1122 & .116 & -3.854 & 0.000 & 0.147 & 0.000 & -0.009 & 0.940 \\
\hline
\end{tabular}

Our final series of graphs links imports and innovation to export status. As our results suggest that imports really drive product innovation, we compare the productivity distributions of exporters versus non-exporters conditional on previous import and innovation status. The results become even more striking showing an even stronger complementarity between import/product innovation on the one hand and exports on the other. Table 13 compares the distributions formally showing the results consistent with the graphs. ${ }^{7}$

Import \& Product Innovation

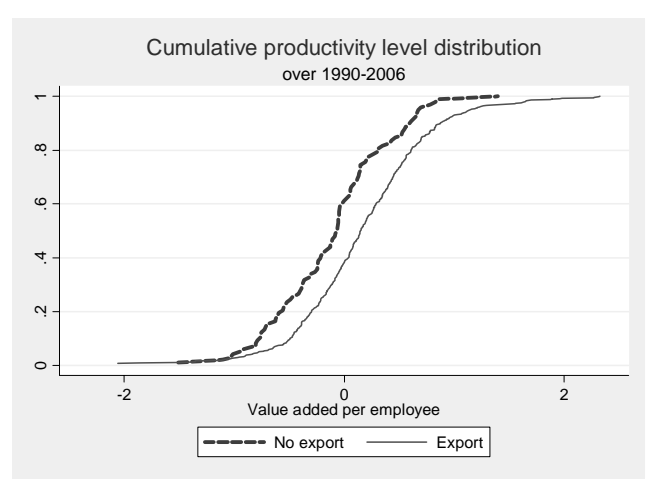

No import \& No product innovation

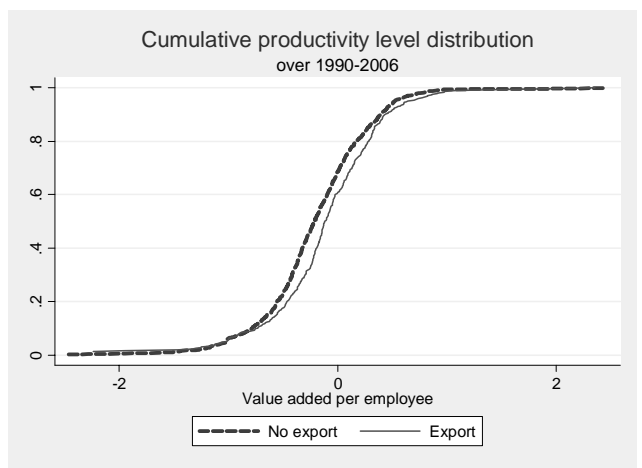

${ }^{7}$ Note that a direct test of complementarity can be constructed by testing if the difference in productivity differences between exporters that import and innovate in product and non-exporters that import and innovate in product (0.271) is significantly larger than the difference in productivity between exporters and non-exporters that do not import nor innovate in product. 
Table13

Difference in labor productivity levels for the firms with import \& product innovation: exporters versus non-exporters

\begin{tabular}{|l|c|c|c|c|c|c|c|c|c|}
\hline & $\begin{array}{c}\text { Number } \\
\text { of firm- } \\
\text { year obs. }\end{array}$ & $\begin{array}{c}\text { Differen } \\
\text { ce in } \\
\text { means }\end{array}$ & \multicolumn{2}{|c|}{$\begin{array}{c}\text { Mean (non- } \\
\text { exporters)> } \\
\text { mean (exporters) }\end{array}$} & \multicolumn{2}{|c|}{$\begin{array}{c}\text { K-S test for } \\
\text { equality of } \\
\text { distributions }\end{array}$} & \multicolumn{2}{|c|}{$\begin{array}{c}\text { Difference in favor } \\
\text { of exporters }\end{array}$} \\
\hline & 1 & 0 & & \multicolumn{2}{|c|}{ t-statistic } & P-value & D & P-value & \multicolumn{2}{|c|}{ D } & P-value \\
\hline
\end{tabular}

\section{Conclusions}

\subsection{Basic Findings}

- Selection of firms into the export market is non-random: firms make productivity enhancing investments and as a result the more productive firms start an export activity, which might make these firms even more productive.

- We find evidence of two types of productivity enhancing investments made by Catalan firms:

- The fact that the firm imports some of its inputs seems to positively affect productivity and, hence, exports.

- The fact that the firm has innovated in the previous year seems to positively affect productivity.

- Catalan exporters do seem to enhance their productivity even after having made these productivity enhancing investments.

- Exports are very persistent. Once a firm enters the export market it is very likely to remain in the export market for a while. This is consistent with the fact that there are sunk costs to enter export markets.

- Exports are directly affected by imports and innovation. There is an important difference between the effects of product innovations versus process innovations: product innovations seem to matter more for the export decision of Catalan firms while process innovations have little or no effect on this decision. This is in line with the earlier literature on the internationalization process of firms where firms enter into the export market after having developed new products for the domestic market.

- Innovation is directly affected by imports. We find evidence of the following succession of activities by the firm. Firms import and as a result generate better new products. Most product innovations are related to new designs and/or presentations of the product and less to new components, new materials or new intermediate products. This suggests that Catalan 
importers provide some value adding transformations of the product. This in turn allows these firms to enter the export market.

\subsection{Policy Conclusions}

- Internationalization of firms, and exporting in particular, is not independent from other investment decisions made by the firm. Based on our analysis we would even argue that imports and innovations precede the successful entry of firms into the export market. Therefore, innovation policy and access to international (technology) markets (imports) directly affect and enhance the export decision. These investments together with the exporting decision identify the most productive Catalan firms.

- Somewhat counter to common wisdom, import decisions seem to matter a lot for identifying productive Catalan firms. Through access to more varieties of intermediate inputs, to higher quality inputs and through learning effects these firms improve their productivity. In addition these firms are more likely to innovate. Focusing policies more broadly on helping firms access international markets rather than developing policies narrowly and solely focused on getting firms to export would aid in improving the health of many Catalan firms.

- Product innovation and not process innovation seems to identify the productive Catalan firms. The fact that Catalan firms do not innovate much, and when they do innovate they innovate in processes, reflects that Catalan firm are predominantly active in low to medium tech markets and more mature markets. Stimulating the product innovators in higher tech markets will improve the health and resilience of the Catalan economy.

- Consistent with earlier work, policy makers should stimulate Catalan firms to be active on the international (technology) market sourcing new technology and higher quality inputs and to innovate in new products instead of spending resources on attracting foreign firms, which in the end do not generate that many externalities to the local environment.

- The integration of CIDEM and COPCA, decided in 2007, is a step in the right direction. However, we believe that a more explicit connection between innovation and internationalization of activities is necessary. Furthermore, there is currently no attention paid to the import side of the internationalization process. Note that this is related to the outsourcing decisions made by firms.

- We find that importing, innovating and exporting are strongly complementary activities. But at the same time these activities are developed sequentially by the firms. Therefore, it seems that stimulating firms to be active in the international sourcing market and generating innovations might be more productive policy measures than stimulating firms to enter the export market. Given the lead time needed in importing and innovating, it is less likely that export promotion measures will be very successful in feeding back into future importing and innovating in order for firms to be able to successfully enter the export market. Rather the opposite should happen, where firms are stimulated to import and innovate. The next logical step for these firms is then to enter the export market. 


\section{References}

Amiti, M. and J. Konings, Trade Liberalization, Intermediate Inputs and Productivity: Evidence from Indonesia, American Economic Review, forthcoming.

Antras, P. (2005), Incomplete Contracts and the Product Cycle, American Economic Review, 95(4), pp. 1.054-1.073.

Aw B. Y., Roberts, M. J. and T. Winston (2007), Export Market Participation, Investments in R\&D and Worker Training, and the Evolution of Firm Productivity, The World Economy 30 (1), pp. 83-104.

Aw, B. Y. and G. Batra (1998), Technology, exports and firm efficiency in Taiwanese manufacturing, Economics of Innovation \& New Technology 7(2).

Aw, B. Y., Chen, X. and M. J. Roberts (2001), Firm-level Evidence on Productivity Differentials and Turnover in Taiwanese Manufacturing, Journal of Development Economics 66, pp. 51-86

Bartelsman, E. J. and M. Doms (2000), Understanding Productivity: Lessons from Longitudinal Microdata, Journal of Economic Literature 38, p. 3.

Basile, R. (2001), Export behaviour of Italian manufacturing firms over the nineties: the role of innovation, Research Policy 30 (8), pp. 1.185-1.201.

Belderbos, R., Duvivier, F. and V. Van Roy (2008), International and Domestic Technology Transfers and Productivity Growth: Empirical Evidence for Flanders, working paper K. U. Leuven, mimeo.

Bernard, A. and J. Jensen (2004), Why some firms export, The Review of Economics and Statistics 86 (2).

Bernard, A. and J. Jensen (1999), Exceptional exporter performance: cause, effect or both?, Journal of International Economics 47, pp 1-25.

Bernard A., Eaton, J., Jensen, J. and S. Kortum (2003), Plants and Productivity in International Trade, American Economic Review 93(4), pp 1.268-1.290.

Cassiman, B. and E. Martinez-Ros (2007), Product Innovation and Exports: Evidence from Spanish Manufacturing, IESE working paper, mimeo.

Cassiman, B. and R. Veugelers (2004), Importance of international linkages for local know-how flows: Some econometric evidence from Belgium, European Economic Review, 2004, 48(2), pp.455-476.

Clerides, S., Lach, S. and J. Tybout (1998), Is learning by exporting important? Micro-dynamic evidence from Colombia, Mexico and Morocco, The Quarterly Journal of Economics 113(3).

Crepon, B., Duguet, E. and J. Mairesse (1998), Research and Development, Innovation and Productivity: An Econometric Analysis at the Firm Level, Economics of Innovation and New Technology 7(2), pp. 115-158.

Delgado, M., Farinas, J. and S. Ruano (2002), Firm productivity and export markets: a nonparametric approach, Journal of International Economics 57(2), pp. 397-422.

Doraszelski, U. and J. Jaumandreu (2007), R\&D and Productivity: Estimating Production Functions when Productivity is Endogenous, Working paper, Harvard University. 
Ethier, W. (1982), National and international returns to scale in the modern theory of international trade, American Economic Review 72, pp. 389-405.

Fafchamps, M., El Hamine, S., and A. Zeufack (2007), Learning to Export: Evidence from Moroccan Manufacturing, Journal of African Economies, June.

Foster, L., Haltiwanger, J., and C. Syverson (2006), Reallocation, Firm Turnover, and Efficiency: Selection on Productivity or Profitability?, NBER Working paper No. 11555

Griffith, R., Huergo, E., Mairesse, J. and B. Peeters (2006), Innovation and productivity across four European countries, NBER Working paper W12722

Griliches, Z. (1994), R\&D and Productivity: The Econometric Evidence, The University of Chicago Press: Chicago.

Grossman, G. and E. Helpman (1991), Innovation and Growth in the Global Economy, MIT Press, Cambridge.

Hirsch, S. and I. Bijaoui (1985), "R\&D intensity and export performance: a micro view", Weltwirtschaftliches Archiv, 121, pp. 138-251.

Hopenhayn, H. (1992), Entry, Exit and Firm Dynamics in Long Run Equilibrium, Econometrica 60(5), pp. 1.127-1.150.

Huergo E. and J. Jaumandreu (2004), Firms' age, process innovation and productivity growth, International Journal of Industrial Organization 22, pp. 541-559.

Jefferson, G., Huamao, B., Xiaojing, G. and Y. Xiayung (2004), R\&D performance in Chinese industry, Economics of Innovation and New Technology 13 (1/2), Special issue "On Empirical Studies of Innovation in the knowledge driven economy”, Guest editors: B. H. Hall and J. Mairesse.

Jovanovic, B. (1982), Selection and the Evolution of Industry, Econometrica 50(3), pp. 649-670.

Klepper, S. (1996), Entry, Exit, Growth, and Innovation over the Product Life Cycle, American Economic Review, 86, 3, pp. 562-583.

Lileeva A. and D. Trefler (2007), Improved Access to Foreign Markets Raises Plant-Level Productivity ... for Some Plants, Working paper.

Markusen, J. and A. Venables (1998), “Multinational Firms and the New Trade Theory”, Journal of International Economics 46 (1998), pp. 183-204.

Melitz, M. (2003), The Impact of Trade on Intra-industry Reallocations and Aggregate Industry Productivity, Econometrica, 71(6), pp. 1.695-1.725.

Pakes, A. and R. Ericson (1995), Markov Perfect Industry Dynamics: A Framework for Empirical work, Review of Economic Studies 62(1), pp. 53-82.

Roberts, M. and J. R. Tybout (1997), The Decision to Export in Columbia: An Empirical Model of Entry with Sunk Costs, American Economic Review, 87, 4, pp. 545-564.

Vernon, R. (1966), International Investment and International Trade in the Product Cycle, Quarterly Journal of Economics, pp. 190-207. 


\section{Appendix}

\section{Productivity measure}

To measure productivity we construct an index of labor productivity measured as value added per employee for each firm, using a multilateral index developed by Caves et al. (1982) and extended by Good et al. (1997). Our method of computing the productivity index is similar to the methodology used in Aw et al. (2000; 2007) and Delgado et al. (2002). The productivity index is calculated as the logarithm of the value added per employee ${ }^{8}$. To make a comparison between any two firm-year observations possible, each firm's measure of value added is calculated as deviations from a reference firm. The reference firm is a hypothetical firm that varies across industries with output computed as the geometric mean of outputs over all observations. Moreover, since the sampling proportions in our data are different for small and medium ( $\leq 200$ employees) and large firms ( $>200$ employees), the reference firm also varies across size groups. Thus, each firm's output, and productivity for each year are measured relative to this hypothetical firm in the same size group (small or large) and industry.

\section{Kolmogorov-Smirnov equality-of-distribution test}

This non-parametric test rejects the null hypothesis of samples coming from the same populations if there is a point for which the cumulative empirical distributions of two independent samples are significantly different. The testing procedure is based on the concept of first order stochastic dominance. Let $\mathrm{F}$ and $\mathrm{G}$ be cumulative distribution functions of TFP for two subsamples to be compared (in our case, e.g., exporters versus non-exporters). First order stochastic dominance of $F$ relative to $G$ is defined as: $F(z)-G(z) \leq 0$ uniformly for $\forall$ z $\in \mathfrak{R}$ with strict inequality for at least one z. In order to show that F stochastically dominates $G$ we need to conduct the following tests:

-two-sided test : Ho: $F(z)-G(z)=0$ for all $z \in \Re$ versus $H a: F(z)-G(z) \neq 0$ for some $z$;

-one-sided test: Ho: $F(z)-G(z) \leq 0$ for all $z \in \Re$ versus $H a: F(z)-G(z)>0$ for some $z$.

The two-sided test checks the hypothesis on the equality of the distributions $\mathrm{F}$ and $\mathrm{G}$. The distributions $\mathrm{F}$ and $\mathrm{G}$ are not significantly different if we cannot reject Ho for the two-sided test. The one-sided test allows determining whether one distribution dominates the other. Not being able to reject Ho for the one-sided test will mean that $\mathrm{F}$ is equal or to the right of the distribution G.

Thus, in order to show that $\mathrm{F}$ stochastically dominates $\mathrm{G}$ we have to demonstrate that null hypothesis Ho for two-sided test is rejected, while Ho for one-sided test cannot be rejected. This will be consistent with $\mathrm{F}$ being to the right of $\mathrm{G}$.

\footnotetext{
${ }^{8}$ Value added is deflated by a producer price index defined at the two-digit NACE industry level. Source: Instituto Nacional de Estadística de España (www.ine.es).
} 


\section{Definition of a Catalan firm:}

A firm is considered a Catalan firm if most of the plants of the firm are located in Catalonia.

\section{Variable descriptions:}

\begin{tabular}{|c|c|}
\hline Variable & Description \\
\hline Labor productivity level & $\begin{array}{l}\text { Firm specific index of labor productivity calculated as value added per employee } \\
\text { and constructed using a multilateral index (see Appendix for the detailed } \\
\text { explanation on its calculation) }\end{array}$ \\
\hline Export & $\begin{array}{l}\text { Export status dummy, equals } 1 \text { if firm exports at time } t \text { and } 0 \text { if it performs no } \\
\text { exporting activities at time } t\end{array}$ \\
\hline Import & $\begin{array}{l}\text { Import status dummy, equals } 1 \text { if firm imports at time } t \text { and } 0 \text { if it performs no } \\
\text { importing activities at time } t\end{array}$ \\
\hline Product innovation & $\begin{array}{l}\text { Defined in two ways: } \\
\text { 1)Dummy variable equals } 1 \text { if firm carried out product innovation exclusively at } \\
\text { time } t-1 ; 0 \text { - if firm performed neither product nor process innovation at time } t-1 \\
\text { 2) Dummy variable equals } 1 \text { if firm carried out product innovation at time t-1;0 } \\
\text { otherwise }\end{array}$ \\
\hline Process innovation & $\begin{array}{l}\text { Defined in two ways: } \\
\text { 1)Dummy variable equals } 1 \text { if firm carried out process innovation exclusively at } \\
\text { time } t-1 ; 0 \text { - if firm performed neither product nor process innovation at time t-1 } \\
\text { 2) Dummy variable equals } 1 \text { if firm had process innovation at time } t-1,0- \\
\text { otherwise }\end{array}$ \\
\hline $\begin{array}{l}\text { Innovation } \\
\text { "No innovation" case }\end{array}$ & $\begin{array}{l}\text { Dummy variable equals } 1 \text { if firm carried out either product or process innovation at } \\
\text { time } t-1 ; 0-\text { if firm performed neither product nor process innovation at time } t-1 \\
\text { Firm performed neither product nor process innovation at time } t-1\end{array}$ \\
\hline Foreign capital & $\begin{array}{l}\text { Foreign capital dummy, equals } 1 \text { if firm has more than } 50 \% \text { of foreign capital at } \\
\text { time } t\end{array}$ \\
\hline $\begin{array}{l}\text { Definitions of product } \\
\text { and process innovation } \\
\text { in the ESEE survey: }\end{array}$ & $\begin{array}{l}\text { Product innovation: } \\
\text { - whether a firm obtained product innovation in a given year - new products, or } \\
\text { products with new features that are different from those that a firm produced in the } \\
\text { previous years. If the answer is yes, the type of modification is asked: } \\
\text { - incorporates new materials } \\
\text { - incorporates new components or intermediate products } \\
\text { - incorporates new design or presentation } \\
\text { - } \quad \text { the product performs new functions }\end{array}$ \\
\hline & 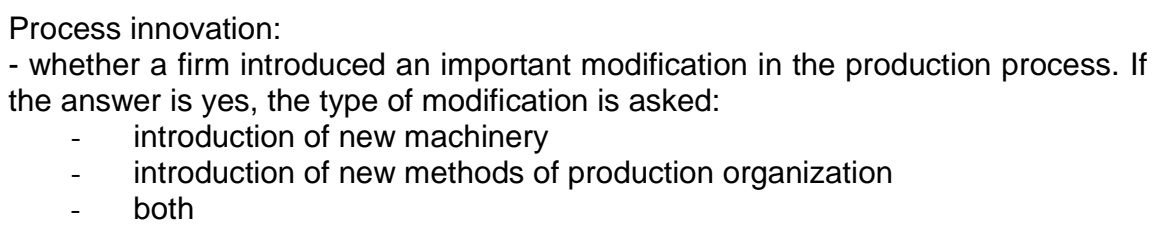 \\
\hline
\end{tabular}

